Journal of African Real Estate Research

Volume 3, Issue 2

\title{
Housing Affordability, Government Intervention and Housing Informality: An African Dilemma?
}

\author{
Basirat A. Oyalowo ${ }^{1}$, Timothy G. Nubi ${ }^{2}$, and Taibat O. Lawanson ${ }^{3}$ \\ 1-2 Department of Estate Management, University of Lagos, Nigeria \\ ${ }^{3}$ Department of Urban and Regional Planning, University of Lagos, Nigeria
}

To cite this article: Oyalowo, B.A., Nubi, T.G. \& Lawanson, T.O. (2018). Housing Affordability, Government Intervention and Housing Informality: An African Dilemma? Journal of African Real Estate Research, 3(2), pp.63-86. DOI: 10.15641/jarer.v0i0.563.

\begin{abstract}
The imperfections associated with housing markets have often been the basis for government intervention policies. The purpose of this article is to show the need for governmental responsiveness regarding local realities in structuring policies in specific sectors of the housing market. It shows how government intervention contributes to housing supply and the consequences of this in developed and developing countries. Conversely, it also explores how government intervention in co-operative societies has been utilised in various countries to address housing supply inelasticity, the outcome of this, and lessons that can be learnt. This study takes the form of a literature review and a quantitative survey of co-operative societies in Lagos, Nigeria. Its analysis is based on multivariate techniques. The quantitative survey is utilised to show a specific case of government inactivity in the co-operative housing sector, while the literature review is utilised to showcase government intervention in co-operative housing in four countries. The study argues that while government interventions (by way of planning regulations) often leads to house-price increases and unaffordability in developed countries, it has contributed to the emergence of informal settlements in several African cities. Additionally, while co-operative societies have been historically recognised to reduce inelasticity, improve supply and affordability in developed countries, they have yet to be recognised and supported in African cities like Lagos. It is concluded that while housing affordability is a dilemma that faces both developed and African countries, informality arises as a uniquely developing country response to unaffordability. It is recommended that, learning from history, African governments should recognise and integrate co-operative societies into their housing supply system. Furthermore, governments should implement appropriate policies to guide their activities towards reducing supply inelasticity, increasing affordability and the reduction of ever-expanding informal communities.
\end{abstract}

Keywords: Co-operative Housing; Co-operative Societies; Government Intervention; Housing Affordability; Housing Informality 


\section{Introduction}

The global quest for housing affordability accentuates the need to see housing as both a social and economic good. Although housing is highly capital intensive, as a social good decent housing has to be made accessible to all income classes in every society. The economic value of housing, on the other hand, lies in the forward and backwards linkages it provides to several industries, opportunities for massive employment generation and its significance as an asset base for most households. However, its dual nature as both a social and economic good has resulted in governments' intervention in the housing market to implement social policies (such as home-ownership or housing affordability) and economic policies (such as revenue generation and fiscal controls). In some cases, these policies achieve positive outcomes, while in others, negative externalities occur. These negative aspects further exacerbate the risks inherent to housing supply with an impact on affordability and accessibility for economically vulnerable groups.

The primary question that this article presents is 'what lessons can be learnt from developed countries in the utilisation of local structures such as cooperative societies to address the prevalence of housing informality in Africa?' Therefore, the purpose of the article is to highlight the need for governments to be more responsive to local realities in structuring policies, especially in specific sectors of the housing market. This is because government policies often produce intended and unintended outcomes, some of which are positive, and others negative for housing affordability. An exploration of the consequences of government intervention in the housing market is important because housing suppliers' reactions to government policies influence the state of housing supply in each particular economic and national context. This is because it is their decision on whether to produce, when to produce and how to produce housing that affects the elasticity of supply and house prices, among others.

Interestingly, governments will often respond to housing suppliers' reactions by way of more regulations which could also yield both polarised, intentional and unintentional consequences. The interplay of these market and regulatory forces, arising from the uniqueness of the dual nature of the housing market contribute to its highly imperfect nature. This study seeks to explore aspects of these dynamics, with the aim of offering insights and lessons from both the global North and South to benefit housing policy-makers in African cities. Furthermore, this study also contributes to the literature on housing systems in general.

This paper is laid out in four sections. The first section shows how government intervention (by way of planning regulations) in the housing market of developed countries have produced reactions from housing suppliers that brought about unintended adverse outcomes. The second explores how government policies have led to a different dimension of unintended adverse outcomes in African cities. Conversely, the third section shows how, in developed countries, government intervention in the cooperative housing market has generated positive outcomes for house prices and affordability. These sections are based on extensive literature reviews. Finally, the fourth section presents the findings of a quantitative survey. It 
questions the extent to which the co-operative sector in one of Africa's most populous cities (Lagos, Nigeria) could be utilised as a deliberate tool for government intervention to bring about positive changes in housing affordability and a check on informal settlement proliferation in the state. A survey of co-operative leaders and analysis of findings provides an overview of the need for a re-direction of government policy to address local realities, especially in cities where there are abundant opportunities for collaborating with existing networks.

\section{Literature Review}

\subsection{Housing Suppliers and Affordability in Developed Countries}

In every country, the urban planning system has the role of mediating land use activities in response to the fixed nature of land supply and the competitive uses to which land is to be put. Furthermore, these systems also determine the level and the rate at which land is released for development. The planning system is said to affect housing supply in three ways; by regulating the amount of land that is made available in a given period of time; two, the length of time it takes for land to be released or approved for construction; and three, the (un)certainty of obtaining planning permission (Mayer \& Somerville, 2000; FTI Consulting, 2012; Monkkonen \& Ronconi, 2013). The planning system and the regulations that condition it, are both firmly in the control of governments.

Like all profit-seeking producers, housing developers analyse market opportunities and the possibility of maximising their profits, which in turn, influences their decision to construct housing units. Thus, when there is both sufficient demand for new developments, and housing developers expect to earn an adequate return on their investment, they will respond by purchasing land and other resources needed to produce housing and put them on the market. Thus, their actions achieve equilibrium in the short-term. Often, the decision to develop housing stems from the availability of incentives to do so, and the absence of government restrictions and delays in the process.

Researchers such as Glaeser and Ward (2009), Paciorek (2013) and Gyourko and Molloy (2014), suggest that the response rate of suppliers to changes in market conditions are sluggish, arising from both governmental and nongovernmental induced factors. Importantly, Worthington (2012) observes that strong housing demand with either limited or slow-to-react housing supply are the most obvious and cited reasons for increases in house prices with an associated negative effect on housing affordability. These factors, in turn, then justify more government intervention in the market for particular groups. Government intervention comes by way of regulations which also influence the quality, quantity, and pricing of housing. This is evidenced in current research that shows housing supply is reduced where there are strict land use regulations which increase the cost of housing production and hence house prices (Mayer \& Somerville, 2000; Monkkonnen \& Ronconi, 2013). Literature in the US hypothesises that cities with more stringent land-use regulations have lower housing supply elasticity, and hence higher housing and land prices (Monkkonnen \& Ronconi, 2013). Higher demand for housing would lead to increased pricing in areas that are constrained by governmental or geographical restrictions to supply more housing. However, in areas that 
are not so constrained, construction activities increase. In addition, Glaeser and Gyourko (2017) highlight that when building activities are unrestricted by regulation or geography, housing supply curves seem relatively flat, so that production costs remain low. Hilber and Vermeulen (2010) further note that a lack of house-building activity is coupled with strong demand and increased house prices, which in turn, has a negative impact on access to housing for first-time buyers.

In general, these studies posit that in developed countries, the theoretical implications of government intervention occasioned by regulation are the emergence of financial and time costs that increase supply inelasticity. This trend is due to the unwillingness of suppliers to take such risks. This reduces housing supply, increases house prices, and hence reduces housing affordability for vulnerable households. In the next two sections, similar issues of housing affordability are considered in the African setting, in which housing supply is held in a different context, and the responses of a predominantly informal housing supply network to government's policies have produced different outcomes.

\subsection{Affordability, Housing Suppliers and Informality: The African Experience}

The formal market supplies only a minor proportion of housing in African cities. In a country like Nigeria, the formal sector's annual supply is about 100,000 housing units compared to 900,000 units supplied by the informal sector (The World Bank, 2016). Housing in informal communities is mainly to be found in the inner cities and the peri-urban communities close to cities.

Over time, these informal settlements take on the characteristics of slums, conceptualised by The World Bank (2008) as the physical manifestation of several overlapping forces such as deep poverty, unrealistic regulatory frameworks, ill-conceived policies, inadequate urban planning, weak institutional capacity, and macroeconomic factors. As shown in Figure 1, the slum penetration ratio in urban Africa is quite high, with $55 \%$ of the urban population living in slum settlements in Sub-Saharan Africa. This ratio is as high as $80 \%$ in Mauritania, $70 \%$ in Niger, $76 \%$ in Sierra Leone, and $50 \%$ in Nigeria. Similarly, according to UN-Habitat (2014), 61.7\% of Sub-Saharan Africa's urban population are slum dwellers. High slum prevalence rates, therefore, signify the response of households to lack of access and affordability of decent housing in the formal sector and dependence on informal suppliers (The World Bank, 2008). 


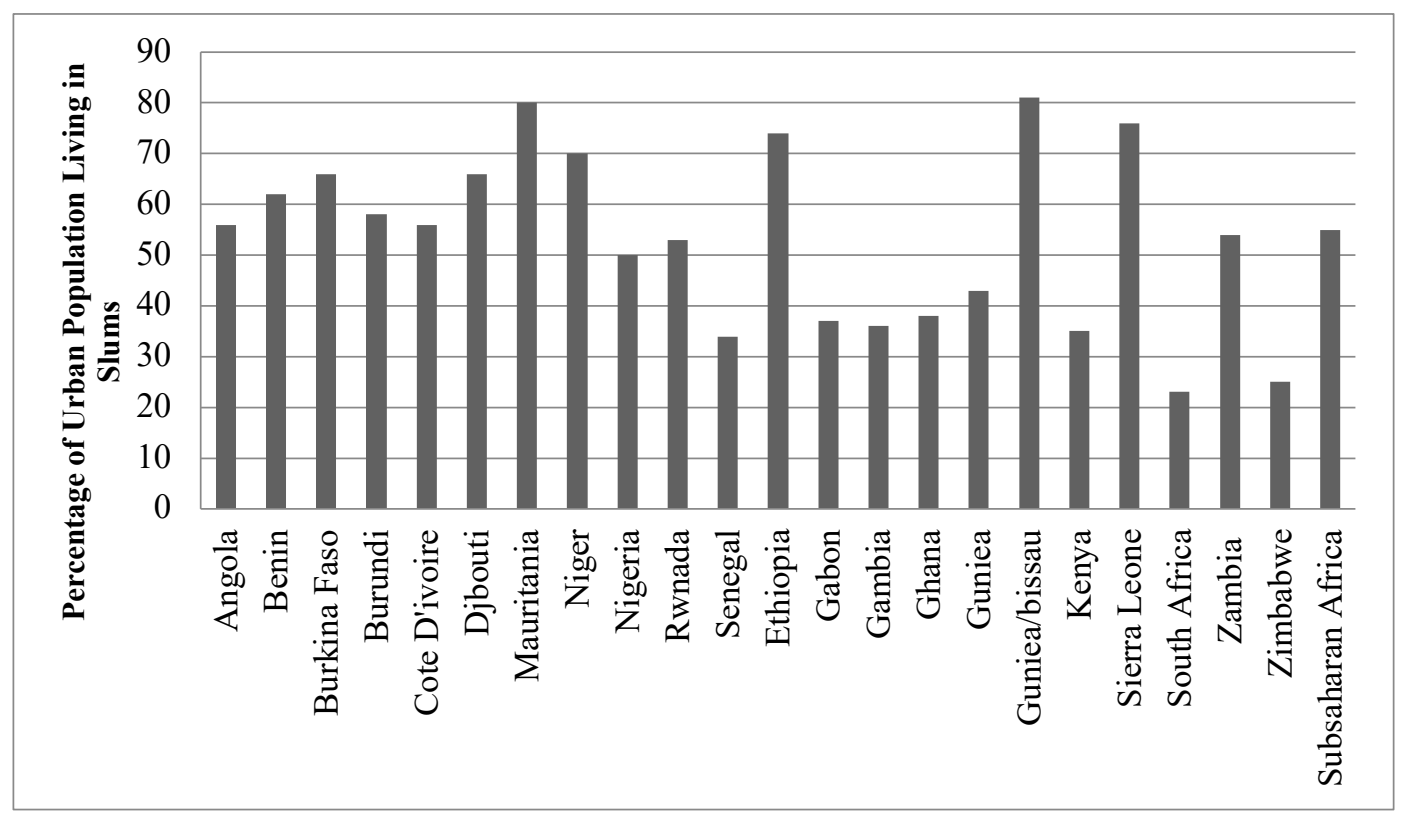

Figure 1: Slum Prevalence in Africa, 2014

Source: The World Bank http://data.worldbank.org/indicator/EN.POP.SLUM.UR.ZS

With a few exceptions, housing markets and housing finance structures in Africa are also still predominantly informal (Centre for Affordable Housing in Africa, 2015). The strategy of divestiture of housing provision to private entities in the formal market (corporate suppliers) has not recorded much success. This is attributable to the lack of development of the financial institutions that make such ventures a feasible and viable one. This is reflected in the lack of access by corporate suppliers to long-term capital market derived funds which are required in financing housing supply. Thus, corporate private-sector housing projects are usually directed towards middle/high-income sales - those who can afford to pay market rates for housing and also qualify for mortgage loans (Eni \& Danson, 2014; Centre for Affordable Housing Finance in Africa, 2015). Those who do not fit this category must, therefore, resort to incremental building and construction, on land purchased in the peripheral areas of the city and inner cities, wherever possible.

The 'affordable' housing in informal communities are therefore mainly supplied by individuals and families. These houses have usually been financed with household savings remittances, loans, and gifts. Since they form a significant proportion of housing suppliers in African cities, the resulting slum proliferation is inevitable (Palmer \& Berrisford, 2015). Also, where a significant proportion of those exhibiting a housing need are in the 'subprime' category, such that they cannot afford market-priced housing, interest in supply by corporate housing developers may not be significant. The implication of this is that households resort to cheaper shelter in informal settlements.

Like the situation in the developed countries, where planning regulations reduce affordability through increased house prices; corporate housing suppliers in Africa are compelled to shift the increased costs of planning 
regulations to house prices and hence cater to the housing demands of the lower proportion of society in the medium to high-income band. However, for the informal suppliers who form the bulk of the market, the reactions are different: they react to costly and lengthy planning processes by merely not adhering to planning regulations, thereby increasing the incidence of substandard housing, and on a larger scale, informal settlements (Centre for Affordable Housing in Africa, 2015; Palmer \& Berrisford, 2015; Bah, Faye $\&$ Geh, 2018). These settlements then become attractive to other low-income home-seekers. Thus, rapid urbanisation coupled with increased housing needs has led to the rapid expansion and proliferation of slums.

\subsection{Outcomes of Government's Policies on Housing Problems}

The preponderance of slum communities in cities has not gone unnoticed by African governments. Palmer and Berrisford (2015) recounts that historically, in the 1950-1960s, governments' responses to housing problems had been the direct construction of public housing and slum clearance programs both of which were largely inefficiently handled. Thus, countries such as Nigeria, Malawi, Zambia, Kenya, and Cote D'Ivoire had to give up their national housing programs when set goals could not be met due to high costs (Palmer $\&$ Berrisford, 2015). Moreover, many African governments soon embraced neo-liberal approaches which had swept global economies in the previous decade, abandoning direct housing provision, taking on an enabler approach and outsourcing much of their social services provision (including housing) to the private sector. Furthermore, and perhaps in response to several calls to reduce the pressure of demand for land and housing services in key cities (UN-Habitat, 2014), several African governments set up satellite towns on the city's periphery. Some of these became slum communities, as the ubiquitous informal settlements spring up to service isolated, higher-income satellite towns.

Clearance of slums and informal communities, which often generates significant inequities and public outrage, continues to be a popular response of governments. For instance, the Zimbabwean government commenced the demolition and burning of slums in Harare and other cities in an attempt to restore order by ridding the cities of illegal housing (Hove, Ngwerume \& Muchemwa, 2013). In Nairobi, Kenya, security reasons were cited in the demolition of the Muoroto and Mwariro slums in the early 1990s (Otiso, 2002). Similarly, in Lagos, Nigeria, recent clearance of Otodo-Gbame informal community and Ijora Badia were as a result of poor living conditions, security concerns and a quest for complementary housing for a 'mega-city' status. However, slum clearance often results in the formation of new slum settlements elsewhere as formal sector housing is not accessible to the populous who reside in these communities. In slum resettlement programmes, demolition takes place and redevelopment/reallocation of new units rarely occurs (Palmer \& Berrisford, 2015). Residents generally move to a new location to create new informal communities.

In the final analysis, it is notable that the limited success achieved by African governments' policies as direct housing suppliers has led to equally unsuccessful divestiture to private, corporate housing suppliers. It is also notable that during periods of intense housing need in countries in Europe and 
parts of Asia; co-operative societies emerged as alternative housing suppliers, and with favourable government policies, they were able to achieve a significant level of success (Cameron \& Wood, 2012). The next section of the paper is devoted to the role of these societies in housing markets across the world.

\subsection{Role of Co-operative Societies in Housing Supply}

Co-operative societies consist of a group of people who have voluntarily come together to enhance their quality of life through working together for the interest of all. The emergence of co-operative societies is generally credited to the Rochdale Society of Equitable Pioneers which was founded in 1844, with membership consisting of a group of 28 weavers and artisans in Rochdale, England. It is also generally known that co-operative societies are traditional institutions of savings mobilisation operated by people all over the world. They are especially popular in Africa. They operate both as social enterprises and economic entities.

In Nigeria, as in most other countries, co-operative societies have been found to contribute significantly to the improved socio-economic circumstances of their members (as evidenced by Olaleye, 2007; Enhancing Financial Innovation and Access in Africa (EFInA), 2012; Aderounmu, Odeyemi \& Adeleke, 2014; Ezekiel, 2014). These expectations have been extended to cooperative activities in the housing sector (Danmole, 2007; Ndubueze, 2009; Nubi, 2015; Lawanson \& Oyalowo, 2016).

Regarding governance, Kennedy et al. (1995) compare the characteristics of co-operatives that make them different from other business organisations and extend this notion to co-operative housing. Since co-operatives are owned and controlled by people who make use of their end products or services, it is governed by a board of directors elected democratically from its membership. The board takes care of general operating policies. Furthermore, cooperatives operate at cost or on a not for profit basis. Since the societies exist to provide services to members, they are charged only the actual cost of running the business, while proceeds generated in excess of actual costs are either refunded to members, kept in the co-operative as a resource of reserve funds, or a combination of both.

\section{Structure of Housing Co-operative Societies}

The structure of housing co-operatives refers to the institutional arrangement on which the co-operative is based and on which it operates. Two structures of housing co-operatives exist. These are market rate housing co-operatives and limited equity housing co-operatives. Market rate housing co-operatives provide members with an appreciation in the value of the property and enable them to sell their shares at market rates, whereas Limited Equity Cooperatives limit the price of membership and set controls in resale values to keep the housing affordable for low, middle and moderate-income residents. Thus, long-term affordability could be assured through a low equity structure (Kennedy et al., 1995). 


\section{The Historical Context of Housing and Co-operative Societies}

Since the end of the Second World War policy measures such as favourable legislation, subsidies and tax incentives were put in place to increase homeownership across Europe. These were strengthened by positive civic attitudes towards home-ownership (Isebaert, 2014). In countries such as Canada, Egypt and Pakistan co-operative societies were expressly utilised by governments to pursue national home-ownership policy in the face of rapid urbanisation (see Bhaiji (2012) for Pakistan, El-Mesiry (2012) for Egypt and Gazzard (2012) for Canada). In others, such as Austria, Ireland and Sweden, co-operative societies started as societies initiated through social reformers and self-help groups, but over time were recognised by the government as an alternative route to housing supply. Therefore, co-operative societies enjoyed favourable government policy to perform this role (see Ludl \& Bauer (2012) for Austria; O'Keeffe \& Sellars (2012) for Ireland and Lago \& Matic (2012) for Sweden). In countries such as Portugal co-operative movements were initially seen as instruments of opposing political structures, but with intense lobbying, followed by a shift to liberalised economic systems, they became recognised and supported by governments.

The general history of co-operative housing reflects the utilisation of a system for addressing a mass housing need as a result of social demand. These conditions are still prevalent in developing countries, where cities are experiencing rapid urbanisation and housing deficits. However, it is also important to recognise how government policy still stands as a significant challenge for co-operative societies' activities in housing supply today. Cooperative societies that had enjoyed a considerable amount of financial support and subsidies from their governments at various times have had to adjust with much strain when governments withdrew support in the face of harsh micro-economic turns. This is especially true for countries like Canada, Turkey, Austria, Poland and Czechoslovakia (now known as the Czech Republic and Slovakia).

The focus of this study, as presented in the next section, is on the period when they enjoyed considerable government support and generated positive outcomes for housing supply. Country case-studies were selected on the basis of relevance of lessons to be drawn for African cities.

\subsection{Government Intervention in Co-operative Societies Housing Supply in Four Countries}

\subsubsection{The United States: A Case of Housing Supply by Both Market and Social Co-operative Societies}

Key Characteristics: There are several categories of housing co-operatives in the United States. There are variants such as the Market Rate Housing Cooperatives, which are sponsored by real estate developers and have middle to high-income households as members (Saegert \& Benitez, 2004). Secondly, there are over 425,000 limited equity housing co-operatives which are established as a result of the need to preserve the affordability of homes for low and moderate-income families. 
Government Intervention: Chicago Mutual Housing Network (CMHN) (2004) notes that historically in the US, housing market constraints have been reduced for co-operative societies through legislation such as the New York Limited Dividend Housing Companies Act of 1927 and the Housing Act of 1949. The University of Wisconsin Centre for Co-operatives (2009) observes that the New York Limited Dividend Housing Companies Act of 1927 was the first significant government program supporting housing co-operative development in the US. Thirteen co-operatives were built under this Act.

New York Housing Act of 1927 promoted affordable housing co-operatives in New York by granting tax exemptions in the increase in value resulting from the construction of new projects for 50 years. The government also supplied low-interest loans (financed by state revenue bonds), state mortgage interest subsidies and special permits for site assemblage at fair prices to developers who agreed to restrict their dividends. Additional favourable intervention occurred in the 1950s, when the Housing Act of 1949 allowed guarantees for market-based loans for new housing co-operative projects, increasing the housing stock. All of these helped to reduce the cost of construction of co-operative housing, thus making it affordable for target households. The case of Limited Equity Co-operatives is particularly important here because they restrict the resale values of co-operative shares to keep them affordable to multiple generations of purchasers by controlling the maximum resale price or by restricting the income of purchasers.

Successes and Shortcomings: According to Sazama (1996), co-operative housing accounts for $17 \%$ of the subsidised housing owned by US public housing authorities. As a result of the tax exemptions granted by the New York Housing Act of 1927 for instance, about 600,000 units of affordable homes for moderate-income earners were developed between 1950 and 1960 by limited profit co-operatives (CMHN, 2004). The shift from direct public investment in the creation of affordable housing also helped in increasing the relevance of co-operative societies in affordable housing supply in the country.

\subsubsection{Austria: A Case of Tight, but Supportive Regulatory Framework for Co- Operatives}

Key Characteristics: The Austrian case-study exemplifies a case of tight government control to achieve a substantive housing policy. The sector represents $8 \%$ of the housing stock in Austria and $15 \%$ of the total multifamily housing stock. It also contributes $15 \%$ (255,000 units) of total rental housing stock and 21\% (113,000) of owner-occupier units as of 2010 (Ludl \& Bauer, 2012).

Government Intervention: The state provides financial support in meeting the uniquely high costs of housing production in Austria. Austria's housing co-operatives are excluded from corporation tax (i.e. taxation on income). They also benefit from long-term and low-interest rate mortgages that cover $20 \%$ to $60 \%$ of the construction costs, which facilitates prompt repayment of mortgages. There are annual grants/loans to cover construction costs, which may be awarded in addition to the mortgages. This has also helped to reduce production costs. In recognition of the capital-intensive nature of housing, the 
proportion of income that is used to finance home-ownership, and in pursuit of the national policy of home-ownership, government intervention in the sector has been necessary. Ludl and Bauer (2012) note that this has resulted in government supporting Austrian co-operatives to provide housing for all income class categories and not only low-income earners.

Successes and Shortcomings: The success of the Austrian housing cooperative societies has been recognised in both the academic and nonacademic literature (Ludl \& Bauer, 2012). One of the major reasons for this has been attributed to the state's financial support in meeting the uniquely high costs of housing production in Austria. However, there are stringent regulatory conditions attached to government intervention. Housing cooperatives are required to focus on continuous housing construction and must acquire permission from the government to interrupt their building activities. They are also subjected to strict financial performance, profitability, management and compliance with obligation checks.

\subsubsection{Portugal: A Case for Co-Operative Advocacy and Lobbying}

Key Characteristics: Housing co-operatives in Portugal provide 3\% of the housing stock at 180,000 units out of 5,880,000 dwellings (Cameron \& Wood, 2012). However, unlike in most other countries, the development of housing co-operatives has been facilitated by strong advocacy and lobbying on their part.

Government Intervention: The centralised state of Portugal regarded the co-operative as a democratic institution and paid only marginal attention to its potential as a source of housing provision. However, they continually lobbied for government support to reduce transaction and production costs associated with housing supply. By the time a democratic state emerged, they were provided financial assistance by the state to cover $85 \%$ to $90 \%$ of the total building and infrastructure costs by way of tax exemption, advantageous long-term loans, financing and supplying the co-operatives with available land. The municipalities also provided land agreements or expropriation (Vilaverde \& Mateus, 2012).

Successes and Shortcomings: Like other countries, state funding declined with the liberated economy of the 1980s. Only construction costs were financed with short-term loans. Still, co-operatives built quality housing at a rate of 30-40\% lower than the market rate due to very low tax rates (Vilaverde $\&$ Mateus, 2012). However, a further decline in state support and the high cost of land led co-operatives to change from low-income housing provision to housing provision for middle and middle-upper income earners. This shows that when exposed to market forces, co-operative societies could still be active in the housing market but should not be expected to provide housing for low-income people without some form of cushioning from the government.

\subsubsection{Egypt: A Stakeholder Support System for Co-operatives}

Key Characteristics: Egypt is a highly urbanised country with a lot of informal housing, squatting and slums (Ede, 2017). Housing co-operatives 
emerged as a result of private initiatives with some state support in the 1930s (Barenstein \& Sanjinés, 2018). Egyptian co-operatives are strictly controlled by the government, mostly urban-based, and have a membership drawn from individuals with similar occupation status with moderate-incomes (El Mesiry, 2012).

Government Intervention: State support significantly increased from the 1970s onwards, when housing co-operatives also became part of a slum eradication strategy (Barenstein \& Sanjinés, 2018). The government actively supported co-operative housing through its legislature. Specific areas of the law stipulate the reduction of taxes on industry and trade profits, interest on deposits in banks and saving funds as well as taxes and fees levied by municipalities. Furthermore, the legislation highlights the national requirements of custom taxes, statistical fees, importing fees and extra fees on imported tools, machines, primary building materials, and means of transportation. Stamp duties paid on contracts are also subject to exemptions and reductions, as are fees on contracts and mortgages, fees for building licenses, land allocation, legal and publishing fees. Furthermore, housing cooperatives receive a $25 \%$ discount on all state-owned land which could go up to $50 \%$ with ministerial approval (El Mesiry, 2012).

Successes and Shortcomings: Egypt's tiered system of co-operative organisation provides coordinated services that substantially reduce costs at various stages in the development process. First, co-operatives are formed to address housing issues. Second, there are four Joint Associations for Building and Housing to support co-operatives in joint projects. They carry out project financing and project management activities, thus providing services that could reduce information and agency costs. Third, the 13 regional associations of co-operatives carry out direct activities that reduce costs for co-operatives in their jurisdictions by supplying housing market data, setting up factories for the purchase, manufacturing and transportation of building materials at the lowest possible prices. Then the apex body, the Federation of Co-operative Housing, provides strategic support, such as: research, training, advocacy, arbitration, auditing, and investment (El-Mesiry, 2012).

The result of government intervention in Egypt is seen in the 2,320 housing co-operative societies that exist today. It is worth noting that one-third of the 80 million Egyptian population are members of these societies (Ede, 2017; Barenstein \& Sanjinés, 2018). In the last 60 years, co-operative societies have supplied over 500,000 dwelling units (Ede, 2017; Barenstein \& Sanjinés, 2018).

These case studies show that co-operative societies have been beneficiaries of government intervention policies that have reduced housing supply costs, increased housing affordability and access for low-income groups in particular. It has also shown that withdrawal of government support reduced the ability of the sector to cope with market rate construction costs. Through a case study of the activities of co-operative societies in Lagos, Nigeria, this study proceeds to explore the potential for their adoption as formal housing suppliers in African cities. Additionally, it assesses the constraints that could limit these and the lessons that can be learnt from other countries that had, at one time or the other, adopted them as alternative suppliers for affordable, 
low-income housing. This required primary data collection and analysis, which is reported in the findings section.

\section{Methods}

\subsection{Research Design}

\subsubsection{Study Area}

The study is set in Lagos, South Western Nigeria. Lagos is Nigeria's commercial hub, which was until 1991 its capital (Lawanson \& Oduwaye, 2014). Due to challenges of poverty, housing deficits and affordability, over $52 \%$ of the population live in multi-dimensional poverty (Lagos State Government, 2013; Oxford Poverty and Human Index, 2016). 70\% of the urban population resides in substandard housing (Lagos State Government, 2013). Almost $75 \%$ of the working population in Lagos rely primarily on the informal economy for income generation (UN-Habitat, 2012; National Bureau of Statistics, 2013).

The overall co-ordination of co-operative societies in Lagos currently lies with the Ministry of Commerce, Industries and Co-operatives. Before this, co-operative affairs had been regulated by the Lagos State Ministry of Agriculture and Co-operatives, which had generated a directory of cooperative societies in the state. The directory forms the basis for the data collected in this study. In expanding the literature on co-operative societies and housing supply in Africa, findings from a survey of co-operative leaders are presented. However, as this paper is an extraction from larger research, only questions relevant to the current discourse are reported.

\subsubsection{Study Population, Sample Frame, Size and Units}

Co-operative societies recorded in the 2015 directory of co-operative societies are the sample units of the study. The directory consists of 2,516 cooperative societies registered in Lagos State Nigeria. The sample size for respondents (these are presidents of co-operative societies) was determined using the formula available online at http://www.raosoft.com/samplesize.html (see Appendix) and is calculated as 334 ; using a $95 \%$ confidence level and 5\% margin of error. This was increased by $80 \%$ so that a total of 600 questionnaires were distributed. Of these, 450 were retrieved with 401 being considered fit for analysis. Thus, a response rate of $75 \%$ was achieved. From the directory, respondents were selected using the systematic random sampling approach.

In order to determine their potentials as housing suppliers, respondents were asked to fill out a structured questionnaire to ascertain the amount of land they held, and the constraints they have faced in constructing housing on that land.

\subsection{Analysis of Findings}

The first question was to determine the amount of land held by co-operative societies. Seventy-one (71) co-operative societies provided details on the lands they held for housing purposes. Out of these, 29 (40.9\%) reported that 
they had up to 10 hectares of land in their possession, $15(21.1 \%)$ had up to 20 hectares of land, $9(12.7 \%)$ had up to 30 hectares. Similarly, $9(12.7 \%)$ had up to 40 hectares, while $6(8.4 \%)$ had up to 50 hectares, and the remaining 3 $(4.2 \%)$ had over 50 hectares of land. This break-down of co-operative land holdings is presented in Table 1.

Table 1: Co-operative Land Acquisition for Housing Purposes

\begin{tabular}{|c|c|c|c|c|}
\hline & Frequency & $\begin{array}{l}\text { Per } \\
\text { cent }\end{array}$ & Holding & Land \\
\hline $\begin{array}{l}\text { Land } \\
\text { (hectares) }\end{array}$ & $\begin{array}{ll}\text { Held } & \\
& F \\
\end{array}$ & $\%$ & $\begin{array}{l}\text { Mid-point (X) } \\
\text { Of Land Held }\end{array}$ & $\operatorname{Total}\left(\mathrm{F}^{*} \mathrm{X}\right)$ \\
\hline $1-10$ & 29 & 40.9 & 5.5 & 159.5 \\
\hline $11-20$ & 15 & 21.1 & 15.5 & 232.5 \\
\hline $21-30$ & 9 & 12.7 & 25.5 & 229.5 \\
\hline $31-40$ & 9 & 12.7 & 35.5 & 319.5 \\
\hline $41-50$ & 6 & 8.4 & 45.5 & 273 \\
\hline$>50$ & 3 & 4.2 & 55.5 & 166.5 \\
\hline Total & 71 & 100 & & 1380.5 \\
\hline
\end{tabular}

These results show that at the minimum, there are at least 1380.5 hectares of land in the possession of the 71 co-operative societies who responded to this question. These are recognised as "landholding co-operatives". The average land holding per co-operative is 19 hectares (1380.5 divided by 71). This can be used to extrapolate first for the 401 respondents in the survey and ultimately, for the entire 2,516 co-operatives in the Lagos database. The 71 land holding co-operatives represent $18 \%$ of the sampled 401 co-operatives. Extrapolating to the entire population of 2,516 co-operatives in the directory suggests that approximately 453 co-operative societies $(18 \%$ of 2,516$)$ may be adjudged to hold approximately 8,605 hectares of land (19 hectares multiplied by 453 ).

Making further assumptions as shown in Table 2, co-operative societies are capable of releasing up to 637,407 housing units into the Lagos affordable housing market.

Table 2: Housing Units to be Potentially Released from Derived CoOperative Land Holdings

\begin{tabular}{l|c}
\hline Parameters & Deductions \\
\hline Total Amount of land held & 8,605 hectares \\
\hline $\begin{array}{l}\text { Amount of land for residential housing development- } \\
60 \% \text { (according to planning standards: Obateru, 2012) }\end{array}$ & 5,163 hectares \\
\hline $\begin{array}{l}\text { Assuming all land is developable and free of litigation; } \\
\text { amount of land for residential housing development in } \\
\mathrm{m}^{2}(5163 \times 10,000)\end{array}$ & $51,630,000 \mathrm{~m}^{2}$ \\
\hline $\begin{array}{l}\text { Standard plots to be obtained: (land size } \div \text { unit plot size) } \\
\left.\text { (standard plot size } 18 \mathrm{~m} \times 36 \mathrm{~m}=648 \mathrm{~m}^{2}\right)\end{array}$ & 79,675 plots \\
\hline $\begin{array}{l}\text { Housing units, at contemporary multifamily units of } 8 \\
\text { units on 4 floors per plot. (8 x 76,675 plots) }\end{array}$ & 613,400 units \\
\hline
\end{tabular}

This analysis, although simplistic and not presented as accurate, indicates the significant potential co-operative societies have for increasing home- 
ownership for their members in Lagos State. However, this land remains unused, and the potential for improving housing supply remains untapped due to the lack of housing construction activities by co-operative societies.

As such, the respondents were then asked to indicate the constraints they face in building up the land into housing units. They were required to state the significance of 57 constraint variables that had been identified in the literature and a pilot study measured on a 7 point-Likert scale ranging from $1=$ Not at all; $2=$ extremely low constraint; $3=$ low constraint; $4=$ partially low constraint; $5=$ partially high constraint, $6=$ high constraint $7=$ extremely high constraint.

In analysing the responses, the factor analysis using principal axial factoring (PAF) with varimax rotation was utilised. PAF allows the reduction of variables in a dataset. Two initial correlation matrices were carried out, both of which showed that several variables had cross-loaded on more than 1 factor during the varimax rotation. These variables were excluded from the analysis so as not to skew the dataset and the procedure re-ran. At the third running, after ascertaining that there were no variables with significantly low and high correlation loadings on other factors, the analysis proceeded with a test of sampling adequacy using Kaiser-Mayer-Olkin (KMO) and Bartlett's Test of Sphericity.

As shown in Table 3, the dataset achieved a score of 0.959 , which is a highly satisfactory score according to Field (2009). The extraction of factors generated a four-factor solution that accounted for about $65 \%$ of the total variance in the data with eigenvalues threshold at 1 and factor loadings at 0. Factors were rotated using varimax rotation, an orthogonal rotational method that assumes no correlation between the factors, and which enhances the fit of item loadings on the factors. Factor 1 accounted for $22.884 \%$ of the variance in the dataset and Factor 2 accounted for $18.853 \%$. While Factor 3 accounted for $11.832 \%$ and Factor 4 accounted for $11.582 \%$. This is shown in Table 4.

Table 3: Test of Sampling Adequacy

\begin{tabular}{|c|c|c|}
\hline \multicolumn{3}{|l|}{ KMO and Bartlett's Test } \\
\hline \multicolumn{2}{|c|}{ Kaiser-Meyer-Olkin Measure of Sampling Adequacy } & .959 \\
\hline \multirow[t]{3}{*}{ Bartlett's Test of Sphericity } & Approx. Chi-Square & 14998.379 \\
\hline & Df & 780 \\
\hline & Sig. & .000 \\
\hline
\end{tabular}

Table 4: Variance Explained by Factors

\begin{tabular}{|c|c|c|c|c|c|c|c|c|c|}
\hline \multicolumn{10}{|c|}{ Total Variance Explained } \\
\hline \multirow[b]{2}{*}{$\begin{array}{c}\dot{0} \\
\stackrel{0}{0} \\
\tilde{c}\end{array}$} & \multicolumn{3}{|c|}{ Initial Eigenvalues } & \multicolumn{3}{|c|}{$\begin{array}{l}\text { Extraction Sums of } \\
\text { Squared Loadings }\end{array}$} & \multicolumn{3}{|c|}{$\begin{array}{l}\text { Rotation Sums of } \\
\text { Squared Loadings }\end{array}$} \\
\hline & $\underset{0}{\pi}$ & 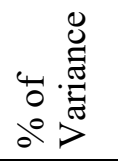 & $\dot{\Xi} \partial^{\circ}$ & 吾 & 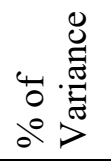 & $\dot{\Xi} \partial^{\circ}$ & 要 & 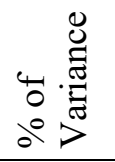 & $\dot{\Xi} \Xi{ }^{\circ}$ \\
\hline
\end{tabular}




\begin{tabular}{|c|c|c|c|c|c|c|c|c|c|}
\hline \multirow[t]{2}{*}{1} & 19.2 & 48.1 & 48.1 & 18.9 & 47.3 & 47.3 & 9.1 & 22.8 & 22.8 \\
\hline & 62 & 55 & 55 & 26 & 15 & 15 & 54 & 84 & 84 \\
\hline \multirow[t]{2}{*}{2} & 4.40 & 11.0 & 59.1 & 4.09 & 10.2 & 57.5 & 7.5 & 18.8 & 41.7 \\
\hline & 5 & 11 & 67 & 4 & 36 & 51 & 41 & 53 & 38 \\
\hline \multirow[t]{2}{*}{3} & 1.88 & 4.70 & 63.8 & 1.56 & 3.91 & 61.4 & 4.7 & 11.8 & 53.5 \\
\hline & 1 & 1 & 68 & 5 & 3 & 64 & 33 & 32 & 69 \\
\hline \multirow[t]{2}{*}{4} & 1.73 & 4.34 & 68.2 & 1.47 & 3.68 & 65.1 & 4.6 & 11.5 & 65.1 \\
\hline & 9 & 8 & 17 & 5 & 7 & 51 & 33 & 82 & 51 \\
\hline
\end{tabular}

Table 5 shows the factor loadings of factors, alongside the items that were loaded on each. Factor 1 has 15 items loading on it, factor 2 has 11 items, factor 3 has 7 items, and factor 4 has 6 items loading. The Principal Axial Factoring utilised for the factor analysis produced a four-factor solution that reduced the variables from 57 to 39. Following established practices in Factor Analysis, Factor 1 represents the factor with the highest weight of influence on the entire database, followed by Factor 2, 3 and 4.

Table 5: Rotated Factor Matrix

\begin{tabular}{|c|c|c|c|c|c|c|c|c|}
\hline & \multicolumn{8}{|c|}{ Rotated Factor matrix } \\
\hline & \multicolumn{2}{|c|}{ Factor 1} & \multicolumn{2}{|c|}{ Factor 2} & \multicolumn{2}{|c|}{ Factor 3} & \multicolumn{2}{|c|}{ Factor 4} \\
\hline & Items & Loading & Items & Loading & Items & Loading & Items & Loading \\
\hline 1. & $\begin{array}{l}\text { Default } \\
\text { recovery }\end{array}$ & .779 & \begin{tabular}{|c} 
Cost of \\
paying land \\
agents \\
\end{tabular} & .797 & $\begin{array}{c}\text { Access to } \\
\text { political } \\
\text { support }\end{array}$ & .776 & $\begin{array}{c}\text { Cost of } \\
\text { building } \\
\text { materials }\end{array}$ & .862 \\
\hline 2. & $\begin{array}{c}\text { Credit risk } \\
\text { profiling }\end{array}$ & .778 & $\begin{array}{c}\text { Clearance } \\
\text { cost }\end{array}$ & .770 & $\begin{array}{l}\text { Collaboratio } \\
\text { n with Banks }\end{array}$ & .752 & $\begin{array}{l}\text { Cost of actual } \\
\text { construction }\end{array}$ & .806 \\
\hline 3. & $\begin{array}{c}\text { Leaders' } \\
\text { experience }\end{array}$ & .773 & $\begin{array}{c}\text { Land } \\
\text { surveying } \\
\text { cost }\end{array}$ & .752 & $\begin{array}{c}\text { Lack of } \\
\text { access to } \\
\text { cheaper } \\
\text { FMBN loans }\end{array}$ & .739 & $\begin{array}{l}\text { Cost of land } \\
\text { preparation }\end{array}$ & .756 \\
\hline 4. & $\begin{array}{c}\text { Members' } \\
\text { loan } \\
\text { diversion }\end{array}$ & .745 & $\begin{array}{l}\text { Security } \\
\text { cost }\end{array}$ & .763 & $\begin{array}{c}\text { Regulatory } \\
\text { barriers }\end{array}$ & .697 & Cost of labour & .752 \\
\hline 5. & $\begin{array}{l}\text { Quality of } \\
\text { members' } \\
\text { collateral }\end{array}$ & .739 & $\begin{array}{c}\text { Searching } \\
\text { cost }\end{array}$ & .762 & $\begin{array}{l}\text { Access to } \\
\text { technical } \\
\text { assistance }\end{array}$ & .676 & $\begin{array}{c}\text { Road } \\
\text { construction }\end{array}$ & .749 \\
\hline 6. & $\begin{array}{c}\text { Members' } \\
\text { defaults }\end{array}$ & .736 & $\begin{array}{c}\text { Allocation } \\
\text { cost }\end{array}$ & .720 & $\begin{array}{c}\text { Activities of } \\
\text { landowning } \\
\text { families }\end{array}$ & .621 & Cost of land & .503 \\
\hline 7. & $\begin{array}{l}\text { Scarcity of } \\
\text { land close to } \\
\text { workplace }\end{array}$ & .624 & $\begin{array}{c}\text { Titling } \\
\text { extra-legal }\end{array}$ & .514 & & & & \\
\hline 8. & $\begin{array}{c}\text { Agreement } \\
\text { on size of } \\
\text { land }\end{array}$ & .616 & $\begin{array}{c}\text { Hiring } \\
\text { surveyors }\end{array}$ & .508 & & & & \\
\hline 9. & $\begin{array}{c}\text { Members' } \\
\text { participation }\end{array}$ & .596 & & & & & & \\
\hline 10. & $\begin{array}{c}\text { Scarcity of } \\
\text { land in } \\
\text { Lagos }\end{array}$ & .595 & & & & & & \\
\hline
\end{tabular}


It is possible to draw analogies with this ranking to infer that the 15 factor 1 items such as: leaders' housing experience, $(0.773)$, determining credit risk profile (0.778), members' previous defaults $(0.736)$, quality of members' collateral (0.739), tendency of members to divert loans $(0.745)$, ability to recover defaults (0.779), low demand for housing loans (0.719) and others shown in Table 5 constitute an influential group of constraints to housing supply by co-operatives in Lagos State. It is observable that all of these relate to governance issues.

The second group of influential constraints are landowners' extra-legal payments (0.652), titling costs (0.670), titling extra-legal costs $(0.514)$, clearance costs, $(0.770)$, allocation costs $(0.720)$, searching costs $(0.762)$, land surveying costs $(0.752)$, security costs $(0.763)$, cost of paying land agents (0.797). These are transaction cost issues, which are non-direct costs associated with housing construction. The third group of constraints relates to lack of access to cheaper loans from the Federal Mortgage Bank (FMBN) (0.739), collaboration with banks (0.752), lack of access to technical assistance (0.676) and lack of access to political support (0.776), amongst others shown in the table. These indicate the lack of support from external stakeholders as a constraint on housing supply by co-operatives in Lagos. Finally, the table shows that the fourth group of constraints are cost of land (0.503), cost of actual construction (0.806), cost of labour (0.752), and cost of building materials (0.862), amongst others- all of which are related to direct housing production costs. Thus, constraints that have affected the housing supply activities of co-operative societies in Lagos relate to governance issues, production costs issues, lack of external support mechanisms and transaction cost issues.

\subsection{Summary of Key Findings}

Basic analysis conducted in this study (see Table 2) suggests that as far as Lagos is concerned, co-operative societies have enough land in their possession to supply over 600,000 housing units to the Lagos affordable housing sector. The survey shows that co-operative societies are constrained from actual housing construction by four groups of factors. These are governance issues internal to the co-operative societies themselves, transaction costs, housing production costs and lack of external support from stakeholders.

\section{Discussion and Recommendation}

The housing need in Lagos, perhaps best exemplifies the shortage of decent homes in Nigeria. The Lagos State Government (2013) estimated a need to supply up to 5 million units with 2 million coming from newly built housing and 3 million to come from upgrading the informal communities in which $70 \%$ of its residents are reported to live in. The government recognises that these deficits cannot be met with a single approach (Lagos State Government, 2013).

Land acquisition in urban Lagos is an onerous task given the existence of dual land markets. Given their collective strength, co-operative societies have been able to assemble several thousand hectares of land in Lagos, which under the 
stated assumptions, could produce up to 600,000 units into the Lagos affordable housing market. This could, at the very least, produce housing for co-operative members, and by extension, provide an alternative to their pursuit of homes in informal communities. These findings corroborate and substantiate the optimism expressed in previous literature such as Danmole (2007) and Ndubueze (2009). Both authors, like this study, assessed the roles of co-operative societies in housing provision in Nigeria and found that there is a positive potential for them to increase housing access to a specific segment of society. However, this remains only a possibility as their land remains undeveloped. The implication is that co-operative societies have unutilised capacity in the form of idle land, while their potential contribution to affordable housing supply in Lagos remains untapped as land acquisition is only the first step in the housing development process.

This highlights the importance of another finding of the study, which is the identification of the constraints that affect the ability of co-operative societies to act as alternative affordable housing suppliers. The survey showed four critical factors that have so far constrained housing supply by the societies.

The first constraint (governance issues) are internal to co-operative societies such as the inability to agree on salient aspects of the housing development process, issues related to membership management, the tendency of members to divert co-operative housing loans to other purposes, and the attitude of members to co-operative leadership. These signify weaknesses in the internal governance of the societies, constraining collective decision making and building distrust amongst co-operative leaders and members. These are unfavourable conditions for such a long-term and capital-intensive process as housing supply. The inability of co-operative societies to address these effectively limits their progression to higher levels in the housing development process, such as infrastructure provision and housing construction. These factors imply that co-operative lands remain undeveloped until these issues are equitably resolved.

Countries like Austria and Egypt have featured stringent governance guidelines in co-operative regulation as to ameliorate these constraints in such a way that their contribution to housing supply remains significant. The Lagos State Government can provide similar regulatory guidance to address the internal governance constraints identified in this study. This can take the form of mandatory capacity building sessions on conflict management for both cooperative leaders and members, setting up a joint credit bureau solely for cooperative societies and their members to support credit checks and even some measure of control on the uses of loans provided to co-operative members. These regulations should be made in collaboration with co-operative societies themselves for enhanced uptake. In Lagos State, the regulatory authority for co-operative societies is the Lagos State Ministry of Commerce, Industry and Co-operative Societies. It has provided some regulations for co-operative societies in the areas of land acquisition (such as ensuring that there is an evidenced consensus between the co-operative society's members and leaders to buy land). However, the Ministry has not offered any support for enabling co-operative societies that already have land to proceed with actual construction. If this regulatory guidance is provided, strategic linkages with institutions that could support the societies can be achieved. In addition, the 
Ministry has inaugurated its co-operative college to help with capacity building for co-operative leaders and members. Improvements in the structure and content of learning programs at the college will improve the relationship between leaders and members of co-operative societies.

The second set of constraints are transaction costs, conceptualised as nondirect costs of production associated with administrative expenses, the acquisition and purchase of inputs, costs of regulatory permits, information seeking, arranging contracts and all such other costs. Transaction costs are important costs to be met once any developer purchases land and co-operative societies are not exempt. They are either market-based (as in the cost of fencing), subject to contractual or professional fees (as in cost of land surveying) and also capable of being negotiated (as in extra-legal payments). The government fixes other categories of transaction costs, such as titling fees, cost of stamp duty and planning permits. In general, the varied nature of transaction costs enables them to constitute an entry barrier into the housing supply market, so that co-operative societies need some support to deal with them effectively. While the context is slightly different, it is also possible, as seen in other countries, for the Lagos State Government to provide this support. This can take the form of enactment of legislation to reduce government taxes and levies as done in Egypt, special permits for cooperative site assemblage like the US and land agreements as enacted in Portugal. Greater enforcement of existing extraneous charges can also be carried out by the government agencies. The government can also develop a system of subsidisation of professional fees for co-operative housing activities by liaising with relevant professional bodies to reduce this. These intervention measures would reduce transaction costs significantly for cooperative societies and ease their entry into housing construction activities.

The third set of constraints relates to a lack of external support by core stakeholders to housing supply activities of co-operative societies. Cooperative societies are constrained by a lack of access to state-provided financial facilities such as those provided by Nigeria's apex national housing finance institution (Federal Mortgage Bank of Nigeria, FMBN). They, therefore, lack special financial facilities from banks, technical support, political support as well as the support to check the excesses of the informal land sellers whom they (as well as the general populace) rely on for land assembly. These support systems are crucial to increasing the capacity of cooperative society to manage external constraints they cannot handle by themselves. Furthermore, obtaining support networks requires that cooperative societies reach out in some way to potential supporters. Inability to attract and sustain external relationships is an indication of weak governance structures. In tandem with theories of co-operative governance, such as stakeholder theory and resource dependency theory, co-operative societies should be empowered to identify stakeholders that would be of benefit to their operations and hence engage them for greater efficiencies (Cornforth, 2004; Odera, 2012; Hannan, 2014). However, external support mechanisms can also be galvanised with institutional collaboration between co-operative societies and a knowledge partner, for instance. The knowledge partner such as an advocacy group, housing NGO or even university advocacy centre working in the housing sector could help advocate for government support and 
mobilise for other non-government partners (such as professional bodies) to engage with co-operative housing supply activities.

Variants of this exist in the Egyptian case-study with its four-tiered stakeholder support mechanism, and much of the success of the Portuguese co-operative housing can be attributed to the vigorous lobbying of early cooperatives. This can also be a useful strategy for co-operative societies in Lagos State because there are similar existing structures in place to achieve this. For instance, co-operative societies exist in a three-tiered pyramid structure. At the base of the pyramid are the individual co-operative societies numbering in thousands, also called the primary co-operatives; which form the basis of this study. At the second tier are the 21 co-operative unions, comprising of all primary co-operatives in the same area. The leadership of the unions derive from the leadership of the primary co-operative. In other words, only members of the management committee of the primary cooperative are qualified to stand for elections into the union. At the peak of the pyramid is the Lagos State Co-operative Federation (LASCOFED) which derives its leadership from the union and is referred to as the "mother" of all co-operative societies in Lagos. However, the duties of the co-operative unions and the Federation is limited to only ceremonial functions, while the real work of engaging members is to be found at the base. Despite this, with sheer collective strength, the unions and the Federation can be better aligned to be more active in advocacy activities to bring attention to collection issues facing the sector.

The fourth set of constraints that affects co-operative societies are production costs, which are defined as the costs directly associated with housing construction. Examples are the cost of building materials, cost of labour, and cost of services such as water supply, road construction, electricity, and so on. They are generally market-driven costs and thus experienced by all categories of housing suppliers. As the findings from the survey show, cooperative societies are not exempt from these production costs. This study has identified the cost of land and its preparation, cost of actual construction, cost of labour, cost of building materials and cost of road construction as constraints to housing supply by co-operative societies. The experience in Egypt shows that the co-operative sector had relied on a strong regional cooperative structure to reduce the cost of production. This structure enabled joint purchases, manufacturing and transportation of building materials. In addition, Austria has also been exemplary in its regulations to reduce production costs for co-operative societies, as they are provided with annual grants to cover construction costs (Ludl \& Bauer, 2012). If production costs are substantially reduced, or subsidised, co-operative societies in Lagos would be able to release thousands of units into the market.

Generally, it has been found that co-operative societies have the potential to supply affordable housing in Lagos but are encumbered by constraints in critical steps along the path to housing construction. Although they can address some of these constraints with improved internal capabilities, other constraints require some measure of supportive government intervention to ameliorate. These supportive government interventions are found to be lacking yet have been shown to be instrumental to the development, 
empowerment and success of the co-operative housing sector in the countries presented in the literature review.

The rationale for promoting increased government intervention in the cooperative sector is to enable co-operative societies to operate in the formal sector without the conditions imposed in such markets for the benefit of lower income people. This will help to release more housing into the formal sector; while optimistically, expanding the choices available to these people to live in a decent environment rather than seeking refuge in informal communities that are prone to demolition. Following the Egyptian example where cooperative societies are recognised as part of a slum eradication strategy and Austria where co-operative societies are empowered to supply housing to all income classes, it is critical that the Nigerian governments, both at federal and state level, recognise the potential role of co-operatives in providing affordable housing for their members and other citizens. This recognition must be coupled with an acknowledgement of the impact of this for improving access to formal housing and reducing the proportion of households who inevitably find themselves outside the margin of marketpriced housing and seek solace in informal communities. These notions can be transferred to other African cities.

\section{Conclusion}

Housing affordability is a challenge for most governments in the world today, and governments will intervene in housing markets as a result of this. To ensure affordability, alternative housing markets such as the co-operative sector have been strategically positioned to benefit from specific exemptions to government regulations while also being recipients of favourable policies enacted solely for their benefit. As a result, the co-operative sector has provided thousands of housing units to the targeted low-income sector in developed countries.

This empirical study was designed to draw attention to the potentials of governments in Africa to adopt co-operative societies as partners in housing supply for their predominantly subprime markets. Through a case-study of Lagos, Nigeria, the potential of the co-operative sector in housing supply is deemed to be positive as co-operatives are actively engaged in land acquisition. However, they are unable to proceed to construction (their objective in land acquisition) due to constraints that the study classifies into four groups: governance constraints, production cost constraints; transaction costs constraints and lack of external support.

These constraints are not unique to the Lagos co-operative sector but were also present for co-operative societies in other countries. These include countries such as Portugal, the US, Austria and Egypt (covered in this study), and others such as India, Norway, Poland, Pakistan, Italy. In the above countries, the respective governments have successfully integrated and supported co-operative societies as crucial housing suppliers. They have been used as avenues for tackling housing shortages, increasing ownership opportunities, promoting resident control, housing regeneration, participatory decision-making, and preserving affordability for target groups. Direct fiscal and regulatory policies are two major interventions that governments have 
used to address potential market and non-market constraints, and in many cases, this has produced positive outcomes. Thus, co-operative societies have been supported to enable secure, long-term, and affordable housing to tenants as well as owner-occupiers in these countries.

In addressing housing affordability and in reducing housing informality in African cities, a re-direction of government policies is required. It is essential that each country recognise the structure of its housing market as either predominantly formal or informal and then re-create policies that will support existing networks such as co-operative societies, trade groups and community groups to address these issues in their particular contexts. In the case of cooperative societies, when observed in an era of government regulatory support, they have been veritable sources of affordable housing supply in different climes, thus presenting a case of positive outcomes due to government intervention.

\section{References}

Aderounmu, R., Oyedemi, O. \& Adeleke, M. (2014). The Experience and Responsibility of Cooperative Societies to Poverty Alleviation in Eruwa, Ibarapa Region of Southwestern Nigeria. Developing Country Studies, 4(2), pp.1-8.

Bah, E.M., Faye, I. \& Geh, Z.F. (2018). Housing Market Dynamics in Africa. London: Palgrave Macmillian.

Barenstein, J.U. \& Sanjinés, D. (2018). The Role of Cooperatives in the Provision of Affordable Housing: An Introductory Overview. [Online]. Available at: https://www.espazium.ch/the-role-ofcooperatives-in-the-provision-of-affordable-housing-anintroductory-overview (Accessed $5^{\text {th }}$ March 2017).

Bhaiji, M.S. (2012). Housing Co-operatives in Pakistan. In Profiles of a Movement: Cooperative Housing Around the World, Cameron, J.T. \& Wood, D. (Eds.), CECODHAS Housing Europe-ICA Housing, pp.5457.

Cameron, J.T. \& Wood, D. (Eds.), Profiles of A Movement: Cooperative Housing Around the World. CECODHAS Housing Europe-ICA Housing.

Centre for Affordable Housing Finance in Africa (CAHF). (2015). Housing Finance in Africa 2015: A Review of Some of Africa's Housing Finance Markets. Johannesburg: Centre for Affordable Housing Finance in Africa.

Chicago Mutual Housing Network (CMHN). (2004). Affordable housing cooperative: conditions and prospects in Chicago. Chicago: Chicago Mutual Housing Network.

Cornforth, C. (2004). The Governance of Co-operatives and Mutual Associations: A Paradox Perspective. Annals of Public and Cooperative Economics, 75(1), pp.11-32.

Danmole, T. (2007). Cooperative Housing as a Strategy for Alleviating Housing Problems in Nigeria. In Private Sector Driven Housing Delivery: Issues, Challenges and Prospect, Nubi, O., Omirin, M. \& Afolayan, A.S. (Eds.). University of Lagos. pp 225-236 
Ede, S. (2017). Co-operative Housing in Sharing Cities: Activating the Urban Commons. Chapter 1: Housing. [Online]. Available at: www.shareable.net (Accessed $28^{\text {th }}$ June 2018). pp.30-31.

El-Mesiry, M. (2012). Housing Co-operatives in Egypt. In Profiles of a Movement: Cooperative Housing Around the World, Cameron, J.T. \& Wood, D. (Eds.), CECODHAS Housing Europe-ICA Housing, pp.2226.

Enhancing Financial Innovation and Access (EFInA). (2012). Understanding Co-operatives in Nigeria: A Qualitative Report. Lagos: Enhancing Financial Innovation and Access.

Eni, D. \& Danson, P. (2014). Private Sector Participation in Urban Housing Supply in Calabar, Nigeria. American International Journal of Contemporary Research, 4(8), pp.130-141.

Ezekiel P.O. (2014). A Study on Cooperative Societies, Poverty Reduction and Sustainable Development in Nigeria. Journal of Business and Management, 16(6), pp.132-140.

Field, A. (2009). Discovering Statistics using SPSS. (3rd ed.). London: Sage Publications.

FTI Consulting. (2012). Understanding Supply Constraints in The Housing Market. London: FTI Consulting.

Gazzard, N. (2012) Housing Co-Operatives in Canada. In Profiles of a Movement: Cooperative Housing Around the World, Cameron, J.T. \& Wood, D. (Eds.), CECODHAS Housing Europe-ICA Housing, pp.1517.

Glaeser, E. \& Gyourko, J. (2017). The Economic Implications of Housing Supply. Zell/Lurie Working Paper\#802.

Glaeser, E. \& Ward, B. (2009). The Causes and Consequences of Land Use Regulation: Evidence from Greater Boston. Journal of Urban Economics, 65, pp.265-278.

Gyourko, J. \& Molloy, R. (2014). Regulation and Housing Supply. NBER Working Paper No. 20536. [Online]. Available at: real.wharton.upenn.edu/ duranton/Duranton.../Regulation_and_hous ing supply.pdf (Accessed 27 July 2015).

Hannan, R. (2014). The Institution of Co-Operation: A Pathway from Governance to Spill-Over and Poverty. Journal of Co-operative Organization and Management, 2, pp.34-42.

Hilber, C. \& Vermeulen, W. (2010). The Impact of Restricting Housing Supply on House Prices and Affordability. London: Communities and Local Governments.

Hove, M., Ngwerume, E.T. \& Muchemwa, C. (2013). The Urban Crisis in Sub-Saharan Africa. Stability 2(1), pp.1-14.

Isebaert, J. (2014). The Belgian Housing Policy, its Adverse Effort on Labour Mobility and the Negative Externalities of Homeownership. [Online]. Available at:

http://finances.belgium.be/fr/binaries/BdocB 2014_Q3e_Isebaert tc m307-264669.pdf (Accessed 16 ${ }^{\text {th }}$ February 2018).

Kennedy, T., Jermolowicz, A., Lambert, M., Reilly, J. \& Rotan, B. (1995). Co-operatives: A Housing Alternative for Rural America. Washington DC: US Department of Agriculture.

Lagos State Government. (2013). Lagos State Development Plan 2012-2025. Lagos: Lagos State Ministry of Economic Planning. 
Lagos State Government. (2015). Directory of Lagos State Cooperatives. Lagos: Lagos State Ministry of Agriculture and Cooperatives.

Lago, A. \& Matic, L. (2012). Housing Co-Operatives in Sweden. In Profiles of a Movement: Cooperative Housing Around the World, Cameron, J.T. \& Wood, D. (Eds.), CECODHAS Housing Europe-ICA Housing, pp.70-72.

Lawanson, T. \& Oduwaye. L. (2014). Socio-Economic Adaptation Strategies of the Urban Poor in the Lagos Metropolis. African Review of Economics and Finance, 6(1), pp.140-160.

Lawanson, T. \& Oyalowo, B. (2016). Climbing out of Poverty: The Role of Social Co-Operatives in Lagos, Nigeria. Journal of Environmental Design and Management, 8(1\&2), pp.92-101.

Ludl, H. \& Bauer, E. (2012). Housing Co-Operatives in Austria. In Profiles of a Movement: Cooperative Housing Around the World, Cameron, J.T. \& Wood, D. (Eds.). CECODHAS Housing Europe-ICA Housing. pp.9-11.

Mayer, C. \& Somerville, C. (2000). Residential Construction: Using the Urban Growth Model to Estimate Housing Supply. Journal of Urban Economics, 4(8), pp.85-109.

Monkkonen, P. \& Ronconi, L. (2013). Land Use Regulations and Urbanization in The Developing World: Evidence from Over 600 Cities. [Online]. Available at: www.fcias.org.ar/wpcontent/uploads/2015/08/31-Inglés.pdf (Accessed 25 ${ }^{\text {th }}$ March 2018).

National Bureau of Statistics (2013). General Household Survey Panel 2010/11. Abuja: National Bureau of Statistics

Ndubueze, O.J. (2009). Urban Housing Affordability and Housing Policy Dilemmas in Nigeria. Doctoral Dissertation. Centre for Urban and Regional Studies, University of Birmingham. [Online]. Available at: etheses.bham.ac.uk/298/ (Accessed 12 ${ }^{\text {th }}$ September 2017).

Nubi, T. (2015). Housing Beyond Bricks and Mortar. Lagos: University of Lagos Press.

Odera, O. (2012). Corporate Governance Problems of Savings, Credit and Cooperative Societies. International Journal of Academic Research in Business and Social Sciences, 2(11), pp.89-103.

O'Keeffe, N. \& Sellars, D. (2012). Housing Co-operatives in Ireland. In Profiles of a Movement: Cooperative Housing Around the World, Cameron, J.T. \& Wood, D. (Eds.). CECODHAS Housing Europe-ICA Housing, pp.42-45.

Olaleye, Y.M. (2007). Strategies of Co-Operative Societies in Poverty Alleviation Among Urban Dwellers Communities in Ibadan, Oyo State, Nigeria. The Social Sciences, 2(3), pp.365-369.

Otiso, E. (2002). State, Voluntary and Private Sector Partnerships for Slum Upgrading and Basic Service Delivery in Nairobi City, Kenya. Cities 20(4), pp.221-229.

Oxford Poverty and Human Development Initiative. (2016). Multi-Poverty Index Report: Nigeria 2015. [Online]. Available at: www.ophi.org.uk (Accessed $21^{\text {st }}$ October 2017).

Paciorek, A. (2013). Supply Constraints and Housing Market Dynamics. Journal of Urban Economics, 77(1), pp.11-26.

Palmer, I. \& Berrisford, S. (2015). Urban Infrastructure in Sub-Saharan Africa- Harnessing Land Values, Housing and Transport. Cape Town: African Centre for Cities. 
Saegert, S. \& Benitez L. (2005). Limited Equity Housing Co-Operatives: Defining a Niche in the Low-Income Housing Market. Journal of Planning Literature, 19, pp.427-438.

Sazama, G. (1996). A Brief History of Affordable Housing Co-Operatives in the US. Connecticut: The University of Connecticut.

The University of Wisconsin Centre for Cooperatives. (2009). Research on The Economic Impact of Co-Operatives. [Online]. Available at: http://reic.uwcc.wisc.edu/downloads/(Accessed $5^{\text {th }}$ May 2018).

The World Bank. (2008). Approaches to Urban Slums. Washington D.C: The World Bank Group.

The World Bank. (2016). From Oil to Cities, Nigeria's Next Transformation. Washington D.C: The World Bank Group.

UN-Habitat. (2012). World Urbanization Prospects. Nairobi: The United

Nations Commission for Human Settlement.

UN-Habitat. (2014). The State of African Cities 2014. Nairobi: The United

Nations Commission for Human Settlement.

Vilaverde, G. \& Mateus, A. (2012). Housing Co-operatives in Portugal. In Profiles of a Movement: Cooperative Housing Around the World, Cameron, J.T. \& Wood, D. (Eds.). CECODHAS Housing Europe-ICA Housing, pp.62-65.

Worthington, A.C. (2012). The Quarter Century Record on Housing Affordability, Affordability Drivers and Government Response Policies in Australia. International Journal of Housing Markets and Analysis, 5(3), pp.235-252.

\section{Appendix}

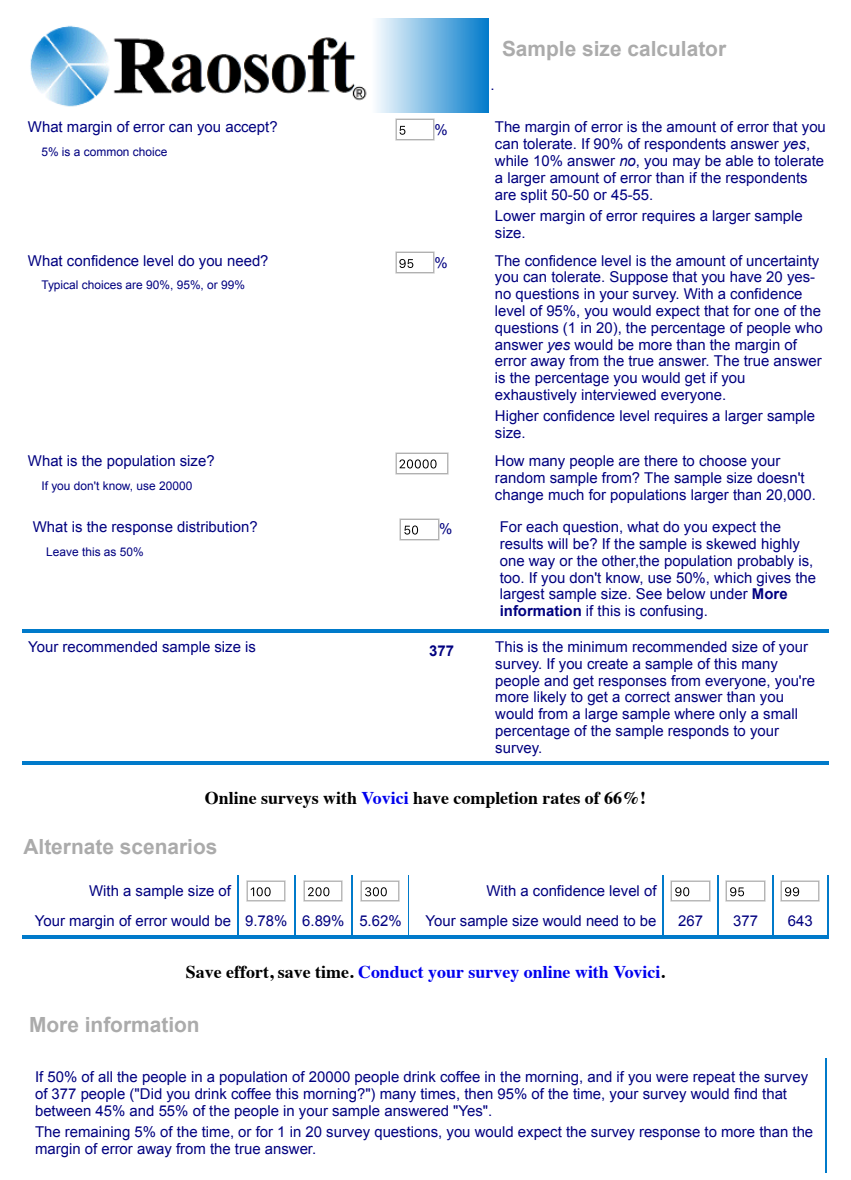

